\title{
Sources of Information Utilized for Job Placement at Nangarhar, Laghman, and Kunar Universities
}

\author{
Mohammad Rahim Rahimi ${ }^{1}$, Abdul Wahid ${ }^{2}$, Muhammad Hassan Mohammadi ${ }^{3}$ \\ ${ }^{1}$ Assistant professor, Department of Agricultural Economics and Extension, Nangarhar University, Nangarhar province, \\ Afghanistan \\ ${ }^{2}$ Teaching Assistant, Department of Agricultural Economics and Extension, Sayed Jamaluddin Afghani University, Kunar \\ province, Afghanistan
}

${ }^{3}$ Senior Teaching Assistant, Department of Agricultural Economics and Extension, Sayed Jamaluddin Afghani University, Kunar province, Afghanistan

\begin{abstract}
The present investigation was carried out at, Nangarhar, Laghman and Kunar Universities Eastern zone of Afghanistan during 2019. Data were collected from 120 final year students from B.Sc. Agriculture Faculty. Studying with the help of structured presented interview schedule to know the Sources of information utilized for job placement. The study revealed that most of the students in general used mass media sources to a maximum extent followed by informal and formal Sources. Among the mass media sources, most of the students used website followed by Newspaper and Journals. Among informal sources and University, placement cell followed by Agricultural majority of the students utilized officers and consultants among formal sources in general. Most of the students used formal source of information (website) in Nangarhar, kunar and laghman (72.50\%), (62.50\%) and $(70.00 \%)$ respectively. where in the informal source of information which is used by the students in Kunar, Laghman and Nangarhar Universities were friends $75 \%, 70 \%$ and $55 \%$ respectively.
\end{abstract}

KEYWORDS: Formal Source, Informal sources, Mass Media Sources

\section{INTRODUCTION}

Hiring high-quality employees remains a primary goal of academic institutions because there will always be hard-to-fill vacancies for which organizations must compete fiercely to attract potential applicants, and the most talented job seekers also continue to have enough options to compare potential employers (Ployhart, 2006). According to Birkwood, this is very important from a strategic point of view. It concludes that by improving focus on sourcing, an individual can directly improve the bottom line and overall financial health of the company (Birkwood,2012).

The different channels can be categorized into modern and traditional sources with modern channels being social media like LinkedIn, Facebook etc., and traditional channels being ads, employee referrals, recruitment agencies, etc (Thielsch, et al 2012 ).A 2009 Carebuilder.com survey found that $45 \%$ of more than 2,600 hiring managers reported searching for social networking sites (SNS) to identify job candidates (Brown,2011).

Nangarhar University, which is ranked second among the Afghan Academic and educational institutes, was founded by the minister of education late Ali Ahmad Popal in Shesham Bagh Jalalabad at the time of King Mohammad Zahir Shah. Initially, the University started with only medical faculty, where 48 students were taught by 5 Americans and 3 Afghan professors. Then periodically, it respectably established Engineering, Agriculture, Educational, Languages and Literature, Economics, Sharia, Law and political sciences, Veterinary sciences, science, computer science, Journalism and public administration faculties (schools). Now it has 13 faculties with 73 departments, where 14004 male and female students are enrolled and taught by 467 lecturers. Nangarhar University has spent 55 years of its academic journey.The accomplishment of this half a century journey is the 23005 Alumni, who are trained in different disciplines in order to serve locally and internationally. Both Kunar and Laghman Universities were established in the year 2010 at the time of Hamid Karzai Afghan president. These two universities are affiliated to Nangarhar university. 


\section{International Journal of Current Science Research and Review}

ISSN: 2581-8341

Volume 04 Issue 06 June 2021

DOI: 10.47191/ijesrr/V4-i6-12, Impact Factor: 5.825

IJCSRR@ 2021

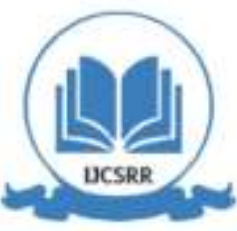

www.ijesrr.org

\section{METHODOLOGY}

The study was conducted during March to April 2019 at Eastern of Afghanistan covering three campuses relating to Agricultural discipline viz., Agricultural faculties Nangarhar, Lughman and Kunar. The population consists of all the final year students of B.Sc. (Agri.) from all the three campuses of the universities.

The data were collected from a purposively selected 120 students (40 from each faculty with the help of well structured, pre - tested interview schedule through interview method. The collected data were analyzed using appropriate statistical tools and the dependent variable is occupational aspiration of students. The salient findings of the study are summarized here under.

\section{RESULTS AND DISCUSSION}

The data on sources of information consulted by students of different colleges for job placements is provided in table 1 . It is observed from the Table that majority of the students in general used mass media sources to a maximum extent followed by informal and formal Sources. Among the mass media sources, most of the students used website $(67.50 \%)$ followed by Newspaper (62.50 \%), Television (35.00\%) and Journals (20.00\%), Friends (66.66\%), Parents (31.66\%), and Relatives (27.50\%), among informal sources and University placement cell (30.83\%), Agricultural officers (26.66\%), and consultants (19.16\%) among formal sources, were utilized by majority of the students in general.

With respect to Agricultural College, Nangarhar Websites $(72.50 \%)$ and journals $(17.5 \%)$ among mass media sources. Friends $(55.00 \%)$, Parents $(22.50 \%)$ and relatives among informal sources and University placement cell (27.50 \%), Consultants $(17.50 \%)$ and Agricultural officers (15.00\%) among formal Sources were consulted by most of the students for job placement. Regarding Agricultural College, Kunar the most utilized sources by the students were Website (62.50\%), Newspaper (62.50\%) and Television (52.50\%) among mass media sources, Friends (75.00 \%), Relatives (45.00\%), and Neighbuors (32.50\%) among informal sources and University placement cell (45.00\%), Consultants (32.50\%) and Agricultural officers (35.00\%) among formal sources.

A large majority of the students of Agricultural College, Laghmah consulted Website (70.00\%), Newspaper (67.50\%), and Television $(27.50 \%)$, among mass media sources. Friends (70.00\%), Parents (40.00\%), and Neighbors (27.50\%), among informal sources and Agricultural officers (30.00\%) and University placement cell $(20.00 \%)$ among formal sources, were consulted by good number of students for job placement information.

Table 1. Sources of information utilized for job placement at Nangarhar, Laghman, and Kunar Universities, Eastern zone of Afghanistan

\begin{tabular}{|c|c|c|c|c|c|c|c|c|c|}
\hline \multirow{2}{*}{$\begin{array}{l}\text { Sl.No. } \\
\text { A }\end{array}$} & \multirow{2}{*}{$\begin{array}{l}\text { Source } \\
\text { Informal Source }\end{array}$} & \multicolumn{2}{|c|}{$\begin{array}{l}\text { Agril.college } \\
\text { Nangarhar }\end{array}$} & \multicolumn{2}{|c|}{$\begin{array}{l}\text { Agril.college } \\
\text { Kunar }\end{array}$} & \multicolumn{2}{|c|}{$\begin{array}{l}\text { Agril.college } \\
\text { Laghman }\end{array}$} & \multicolumn{2}{|c|}{ Total } \\
\hline & & No. & $\%$ & No. & $\%$ & No. & $\%$ & No & $\%$ \\
\hline 1 & Friends & 22 & 55.00 & 30 & 75.00 & 28 & 70.00 & 80 & 66.66 \\
\hline 2 & Relatives & 6 & 15.00 & 18 & 45.00 & 9 & 22.50 & 33 & 27.50 \\
\hline 3 & Neighbours & 3 & 7.500 & 13 & 32.50 & 11 & 27.50 & 27 & 22.50 \\
\hline 4 & Parents & 9 & 22.50 & 13 & 32.50 & 16 & 40.00 & 38 & 31.66 \\
\hline B & Mass Media Sou & & & & & & & & \\
\hline 5 & Website & 29 & 72.50 & 25 & 62.50 & 28 & 70.00 & 81 & 67.50 \\
\hline 6 & Newspaper & 22 & 55.00 & 25 & 62.50 & 27 & 67.50 & 75 & 62.50 \\
\hline 7 & Television & 10 & 25.00 & 21 & 52.50 & 11 & 27.50 & 42 & 35.00 \\
\hline 8 & Journals & 7 & 17.50 & 6 & 15.50 & 11 & 27.50 & 24 & 20.00 \\
\hline 9 & Radio & 2 & 5.00 & 5 & 12.50 & 8 & 20.00 & 15 & 12.50 \\
\hline
\end{tabular}


International Journal of Current Science Research and Review

ISSN: 2581-8341

Volume 04 Issue 06 June 2021

DOI: 10.47191/ijcsrr/V4-i6-12, Impact Factor: 5.825

\begin{tabular}{|l|l|l|l|l|l|l|l|l|l|}
\hline C & Formal Source & \multicolumn{10}{|l|}{} \\
\hline 10 & $\begin{array}{l}\text { University } \\
\text { placement cell }\end{array}$ & 11 & 27.50 & 18 & 45.00 & 8 & 20.00 & 37 & 30.83 \\
\hline 11 & Agril. Officer & 6 & 15.00 & 14 & 35.00 & 12 & 30.00 & 32 & 26.66 \\
\hline 12 & Consultants & 7 & 17.50 & 13 & 32.50 & 3 & 7.50 & 23 & 19.16 \\
\hline 13 & Bank officer & 1 & 2.50 & 10 & 25.00 & 3 & 7.50 & 23 & 19.16 \\
\hline
\end{tabular}

Figure 1. Sources of information utilized for job placement at Nangarhar, Laghman, and Kunar Universities, Eastern zone of Afghanistan

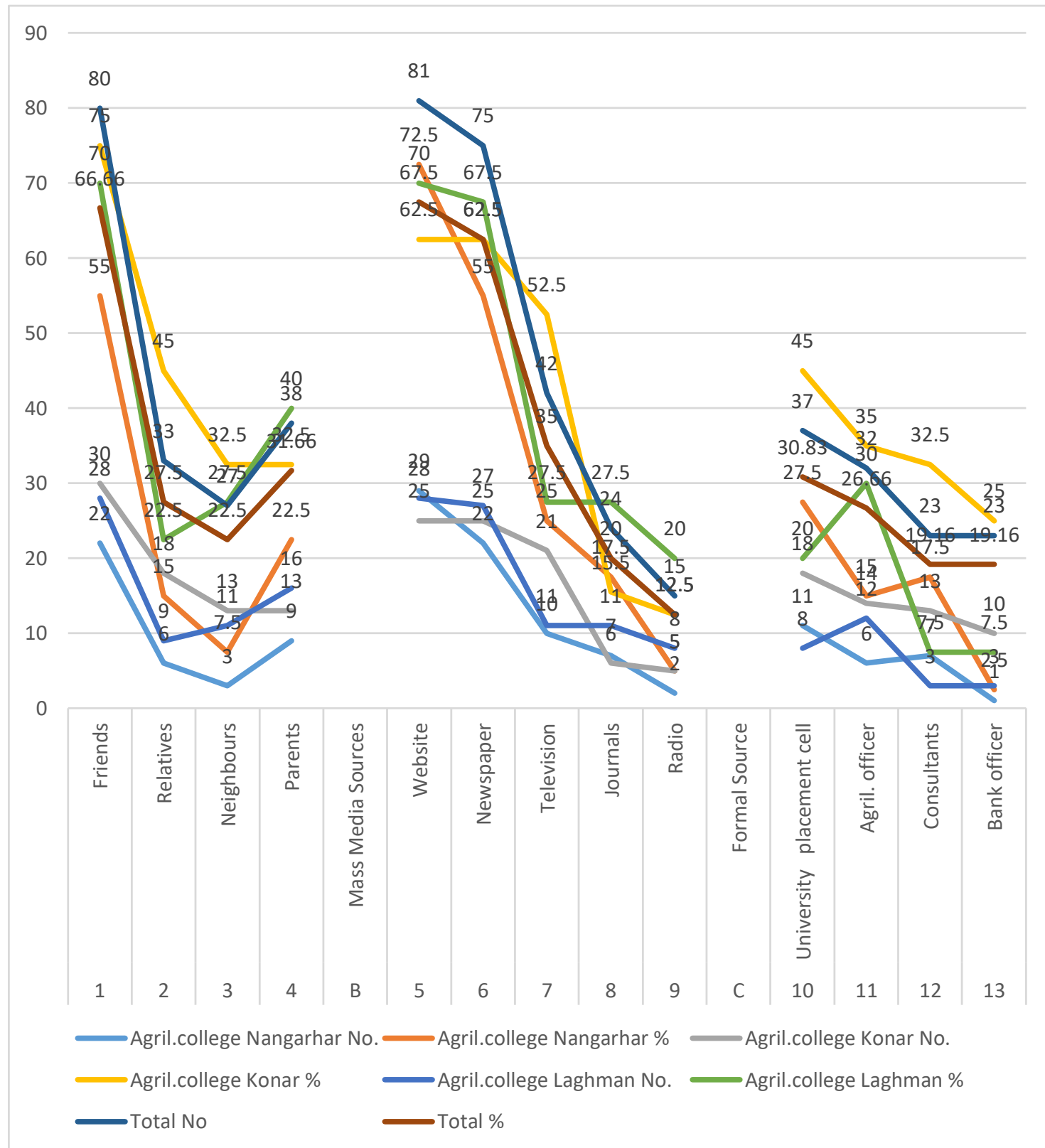




\section{International Journal of Current Science Research and Review}

ISSN: 2581-8341

Volume 04 Issue 06 June 2021

DOI: 10.47191/ijcsrr/V4-i6-12, Impact Factor: 5.825

IJCSRR@ 2021

www.ijcsrr.org

\section{CONCLUSION}

Among the Mass Media sources, most of the students used website followed by Newspaper, Television and Journals, where, informal sources are Friends, Parents and Relatives and among formal sources University placement cell, Agricultural officers, and consultants, were utilized by majority of the students in general.

\section{ACKNOWLEDGMENT}

I thank Ministry of Higher Education, especially Nangarhar University for providing financial assistance during my Research project. It's worth mentioning that Muhmmad Hassan and Abdul Wahid helped me in data collection and technical advices.

\section{REFERENCES}

1. Birkwood, R. (2012). Our Most Effective Source of Hire. A report. Available from: URL: http://www.ere.net/2012/04/05/ourmost-effective-source-of-hir.

2. Brown, V. R., \& Vaughn, E. D.( 2011). The Writing on the (Facebook) Wall: The Use of Social Networking Sites in Hiring Decisions. Journal of Business and Psychology, 26: 219-225.

3. Nangarhar University Wikipedia, the free encyclopedia

4. Ployhart, R. E.(2006). Staffing in the 21st century: New challenges and strategic opportunities. Journal of Management, 32: 868- 897 .

5. Pradhan, G.C.(2002). Factors affecting Occupational Aspiration of College youths. Journal of Educational Research and Extension.39: 38-40.

6. Thielsch, M.T., Traumer, L., \& Pytlik, L. (2012). E-recruiting and fairness: the applicant's point of view. Information Technology Management, 13: 59-67.

7. Warwadekar, S.C., Nirban A.J.and Kadam J.R.(2007). Career Aspirations and needs of the higher secondary school students. Asian Journal of Extension. 27: 46-48.

Cite this Article: Mohammad Rahim Rahimi, Abdul Wahid, Muhammad Hassan Mohammadi (2021). Sources of Information Utilized for Job Placement at Nangarhar, Laghman, and Kunar Universities. International Journal of Current Science Research and Review, 4(6), 574-577 